\title{
Pemanfaatan Ladang Minyak Tua untuk Energi Panas Bumi Komersial: Studi Pendahuluan untuk Aplikasi di Indonesia
}

\author{
Dorman P. Purba ${ }^{1}$, Daniel W. Adityatama ${ }^{1}$, Mukhamad Faeshol Umam², Farhan Muhammad ${ }^{1}$ \\ ${ }^{1}$ Rigsis Energi Indonesia, Jakarta \\ ${ }^{2}$ Pusat Pengembangan Sumber Daya Manusia Minyak dan Gas Bumi, Cepu
}

\begin{abstract}
ABSTRAK
Indonesia memiliki banyak ladang minyak tua dengan komposisi air terproduksi yang tinggi, dimana air terproduksi ini masih dapat dipergunakan untuk kegunaan lain. Salah satu kegunaan dari air terproduksi dengan temperature cukup tinggi ini adalah untuk pembangkit listrik dengan Siklus Rankine Organik (Organic Rankine Cycle / ORC).

Gagasan untuk penggunaan sumur ladang minyak tua untuk pembangkit listrik panas bumi telah lama dipelajari dan didiskusikan di seluruh penjuru dunia untuk mengurangi biaya operasi dari produksi minyak dan gas and untuk memperpankang usia dari ladang minyak yang mulai mendekati akhir masa produksi. Meskipun umumnya reservoir minyak dan gas tidak sepanas reservoir panas bumi konvensional, tetapi beberapa studi menyimpulkan bahwa pada beberapa sumur tua di Texas dan Wyoming memiliki kedalaman yang cukup dengan suhu mencapai $121^{\circ} \mathrm{C}$, dan bahkan beberapa sumur dapat mencapai $210^{\circ} \mathrm{C}$.

Tulisan ini menyimpulkan bahwa pnggunaan lapangan minyak dan gas tua untuk pembangkit panas bumi telah ada contoh sukses di Amerika Serikat dan China. Indonesia memiliki banyak lapangan minyak dan gas yang dapat digunakan untuk fasilitas penggunaan panas bumi. Meskipun begitu, dengan kondisi saat ini dan status teknologi yang masih belum matang dan teruji secara komersil, masih ada beberapa tantangan teknis yang harus dipertimbangkan atau dipelajari lebih lanjut.
\end{abstract}

Kata kunci: Lapangan minyak tua, panas bumi, air terproduksi

\section{ABSTRACT}

Indonesia has a lot of mature oil fields that have high water-cut, where the produced water still has sufficient temperature that can be utilised for other purposes. One of the possible utilisation of the sufficiently high-temperature water from mature oilfield is for geothermal power generation through Organic Rankine Cycle binary power plant.

Worldwide, the idea of utilising oilfield wells for geothermal power generation has been discussed and studied in regard to reduce the operating cost of oil and gas production and to extend the life of ageing and near-depletion oilfields. Although commonly oil and gas reservoir are not as hot as conventional geothermal reservoir, but several studies concluded that some old oil wells in Texas and Wyoming are deep enough to reach the temperatures of $121^{\circ} \mathrm{C}$, and even some of the wells reach $210^{\circ} \mathrm{C}$.

This paper concludes that the use of old oil and gas fields for geothermal plants has been successful examples in the United States and China. Indonesia has many oil and gas fields that can be used for email: dorman.drilling@gmail.com 
geothermal use facilities. However, with the current conditions and technological status that are still immature and commercially tested, there are still some technical challenges that must be considered or studied further.

Keywords: Mature oil fields, geothermal, produced water

\section{PENDAHULUAN}

Eksplorasi dan produksi minyak dan gas di Indonesia telah dimulai sejak lama, dengan eksplorasi pertama yang tercatat pada 1871 , dan dengan produksi komersial pertama pada 1885 di Sumatra bagian timur. Semenjak itu, Indonesia telah aktif pada sektor minyak dan gas dan berlanjut menjadi salah satu pemain penting dalam industry minyak dan gas dengan produksi dari lapangan minyak utama seperti Minas, Duri, Mahakam, Banyu Urip, dan lainnya. Dengan sejarah panjang produksi minyak, tentunya ada banyak lapangan minyak tua yang memiliki kadar air terproduksi yang cukup tinggi. Air terproduksi ini memiliki biaya tambahan untuk pengolahannya, karena dianggap sebagai produk sampingan yang tidak memiliki nilai komersial. Namun, air terproduksi dari beberapa lapangan diketahui masih memiliki suhu yang cukup tinggi untuk dapat dipergunakan pada aplikasi yang lain.

Di beberapa negara, gagasan untuk mempergunakan lapangan minyak untuk tenaga panas bumi telah lama didiskusikan dan diteliti untuk mengurangi biaya operasi dari produksi minyak dan gas dan juga untuk memperpanjang usia komersil dari lapangan minyak yang telah mendekati akhir usia produksinya. Meskipun umumnya reservoir minyak dan gas tidak sepanas reservoir panas bumi pada konvensional, namun beberapa menyimpulkan bahwa pada beberapa sumur tua di Texas dan Wyoming memiliki kedalaman yang cukup dengan suhu mencapai $121^{\circ} \mathrm{C}$, dan bahkan beberapa sumur dapat mencapai $210^{\circ} \mathrm{C}$ (Davis \& Michaelides, 2009).

Tujuan dari tulisan ini adalah untuk merangkum berbagai pengalaman dari seluruh dunia untuk penggunaan air terproduksi dari lapangan minyak tua untuk berbagai keperluan seperti pembangkit listrik atau untuk penggunaan langsung (missal heat exchanger, pegeringan produk agrikultur, dll.). Tinjauan pustaka dilakukan dari berbagai riset dan publikasi untuk mengulas teknologi yang dibutuhkan penggunaan penggunaan tersebut di atas dan juga potensi untuk penggunaan serupa di Indonesia

\section{TINJAUAN PUSTAKA}

Salah satu ciri dari lapangan minyak tua adalah kadar air terproduksi yang sangat tinggi dari dalam reservoir yang harus diolah terlebih dahulu sebelum diinjeksi kembali ke reservoir. Persentase air dibandingkan dengan hidrokarbon dalam produksi umumnya meningkat seiring dengan waktu sampai lapangan minyak tersebut telah kehabisan hidrokarbon dan hanya memproduksi air. Saat ini, kebanyakan lapangan minyak di dunia telah mencapai kadar air terproduksi yang tinggi, berkisar di angka $95 \%$ atau bahkan lebih tinggi (Li, Zhu, \& Zhang, 2012).

Dibandingkan untuk mengolah air terproduksi tersebut dan menginjeksikan kembali, opsi untuk menggunakan panas yang masih tersedia dpat menjadi pilihan yang menarik. Beberapa studi telah dilakukan untuk menggunakan panas dari lapangan minyak tua. Riney (1991) menjelaskan demonstrasi dari penggunaan air panas dari sumur gas di lapangan Pleasant Bayou untuk menghasilkan listrik. Baru baru ini, produksi air panas di lapangan Teapot Dome digunakan untuk menghasilkan listrik menggunakan pembangkit dari Ormat dengan kapasitas $250 \mathrm{~kW}$ dan menghasilkan 1064 MWh dari 2008 sampai 2010 (Johnson \& Walker, 2010). Berbagai studi juga telah dilakukan untuk potensi dari penggunaan panas sisa dari lapangan minyak tua di seluruh dunia dengan berbagai metode (Zhang, Yuan, Liang, \& Li, 2008; Davis \& Michaelides, 2009; Sanyal \& Bulter, 2010; Bu, Ma, \& Li, 2012) 
selain menggunakan ORC, seperti Wellbore Heat Exchanger (WBHX) dan variasi dari ORC seperti pembangkit dengan tipe screw expander (Xin, Liang, $\mathrm{Hu}, \& \mathrm{Li}, 2012)$.

Berdasarkan bagaimana cara panas tersebut di ekstraksi, ada dua jenis pembangkit listrik dari sumur minyak:

- Menghasilkan listrik dari penggunaan air terproduksi dari sumur minyak dan gas yang masih beroperasi.

- Mengubah lapangan minyak tua yang telah habis masa produksi komersialnya (tidak mampu menghasilkan hidrokarbon dengan jumlah komersil) menjadi reservoir panas bumi.

Menggunakan air terproduksi dapat dianalogikan sebagai pembangkit dari panas sisa, karena air terproduksi yang masih cukup panas dapat dipergunakan untuk pembangkit ORC. Listrik yang dihasilkan kemudian dapat dipergunakan untuk menunjang operasi lapangan minyak tersebut atau dapat dijual ke jaringan listrik. Jenis kedua dapat diaplikasikan ketika lapangan minyak tidak dapat lagi menghasilkan hidrokarbon dan hanya memproduksi air. Kemudian operator lapangan dapat mulai untuk mengubah beberapa wellhead atau fasilitas menjadi sumur panas bumi untuk mengakomodir produksi air panas.

Secara umum, ada beberapa metode untuk mengekstrak energy dari air panas pada lapangan minyak tua (Soldo \& Alimonti, 2015):

- Sistem doublet tradisional, melibatkan ekstraksi air panas dari dalam reservoir dan menginjeksikan kembali ke, dan panas diekstrak dengan heat exchanger di permukaan dan digunakan untuk menguapkan working fluid yang menjalankan turbin ORC.

- WBHX, dimana working fluid dialirkan ke sumur untuk mengekstrak panas. WBHX adalah system tertutup dimana tidak melibatkan pengambilan air panas dari bawah permukaan.

Kedua system dapat disambungkan ke system biner ORC atau panas yang dihasilkan dapat digunakan untuk penggunaan langsung seperti pengeringan produk agrikulutur, mirip seperti halnya penggunaan langsung panas bumi. Soldo dan Alimonti (2015) telah menyarankan metode seleksi dengan menggunakan matrix yang dapat digunakan untuk menentukan aplikasi yang paling cocok berdasarkan berbagai aspek dari reservoir seperti temperatur, lingkungan, dan aspek social.

Terdapat beberapa keutungan dari penggunaan lapangan minyak tua untuk produksi panas bumi komersial (Kweik, 2015; Wang, Yan, Li, Hu, \& Li, 2016):

- Karena tempat yang digunakan adalah lapangan yang telah dikembangkan, maka hampir tidak dibutuhkan pembangunan infrastruktur penunjang seperti jalan dan wellpad, sehingga menurunkan biaya awal.

- Data bawah permukaan lapangan umumnya telah diketahui. Tidak diperlukan usaha dan biaya tambahan untuk eksplorasi dan bahkan berpotensi lebih murah daripada mengembangkan lapangan panas bumi baru (green field).

- Permasalahan non-teknis seperti izin, sosial warga sekitar dan lain sebagainya, kemungkinan besar tidak sebesar seperti eksplorasi lapangan baru, karena lapangan yang akan dipakai telah sebelumnya dipergunakan untuk produksi minyak dan gas.

- Reservoir minyak dan gas yang telah habis dapat menjadi ekonomis lagi apabila listrik yang dihasilkan dpat dijual ke grid dan menjadi revenue bagi operator.

\section{A. Pembangkit Siklus Orc}

Reservoir panas bumi suhu tinggi $(\mathrm{T}>$ $220^{\circ} \mathrm{C}$ ) umumnya menggunakan kombinasi dari pembangkit flash steam dengan turbin uap konvensional. Namun, untuk sumber daya panas bumi temperature sedang-rendah $\left(100-220^{\circ} \mathrm{C}\right)$ umumnya menggunakan pembangkit binary. Salah satu pembangkit binary yang banyak dipergunakan untuk sumber daya suhu rendah adalah pembangkit tipe ORC (Hettiarachchi, Golubovic, Worek, \& Ikegami, 2006). ORC berbeda dengan 
flash steam system dimana fluida perantara digunakan untuk memutar turbin sehingga air panas dari dalam bumi tidak bersentuhan langsung dengan turbin. Air panas digunakan untuk menguapkan working fluid yang kemudian akan menggerakkan turbin. Gambar 1 dan Gambar 2 menunjukkan sekma pembangkit ORC dan unit screw expander yang digunakan di lapangan Huabei. Pembangkit ORC umumnya menggunakan hidrokarbon atau hidrokarbon terfluorinasi sebagai working fluid (Li, Zhu, \& Zhang, 2012).

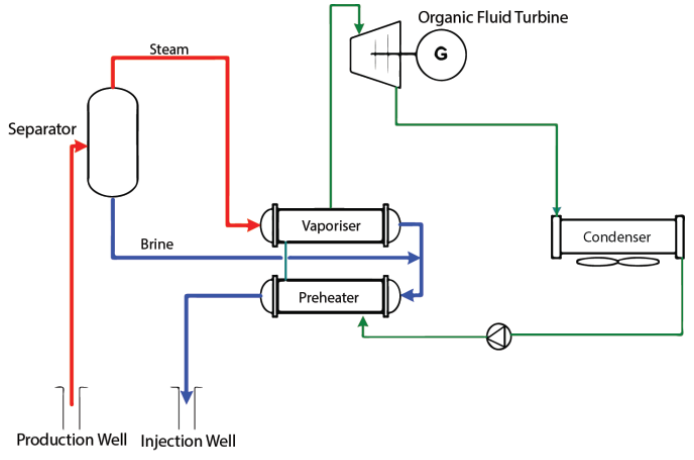

Gambar 1. Skema pembangkit ORC

Proyek percobaan di lapangan Teapot Dome, Wymoing, dilakukan dengan menggunakan pembangkit ORC dari Ormat dengan kapasitas 250kW (Johnson \& Walker, 2010). Unit ORC disuplai dengan 40,000 bpd air terproduksi dengan suhu $76^{\circ} \mathrm{C}$ dari formasi Tensleep untuk menguapkan working fluid isopentane. Pembangkit ORC tersebut beroperasi dari September 2008 sampai dengan Februari 2009, memproduksi total 568 MWh listrik.

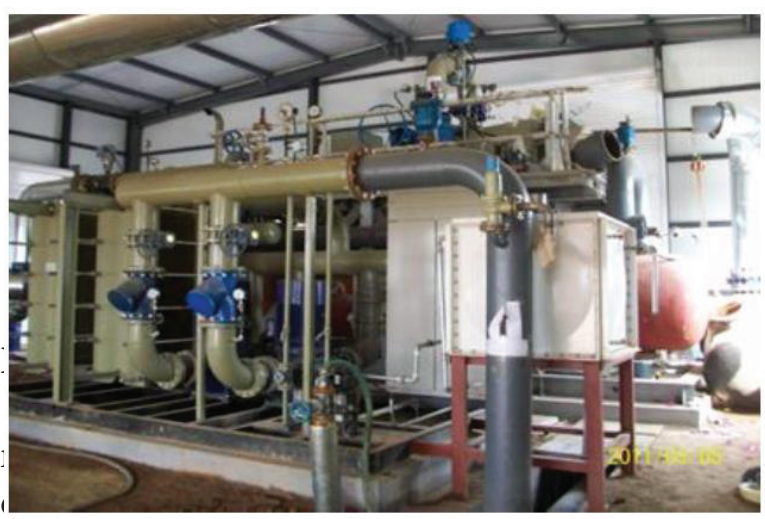

Gambar 2. Binary screw expander turbin di lapangan Huabei (Xin, Liang, Hu, \& Li, 2012) lain, merupakan system loop tertutup dimana tidak ada transfer fluida dari sumur dan formasi. Working fluid dari permukaan disirkulasikan ke dalam sumur melalui saluran berbentuk cicncin, dan dalam perjalanan turun ke bawah sumur working fluid akan dipanaskan oleh formasi seki$\operatorname{tar}(\mathrm{Bu}, \mathrm{Ma}, \& \mathrm{Li}, 2012)$. Aliran fluida kemudian dialirkan balik ke atas dari ujung bawah sumur, dan kemudian fluida naik kembali ke permukaan (Gambar 3)

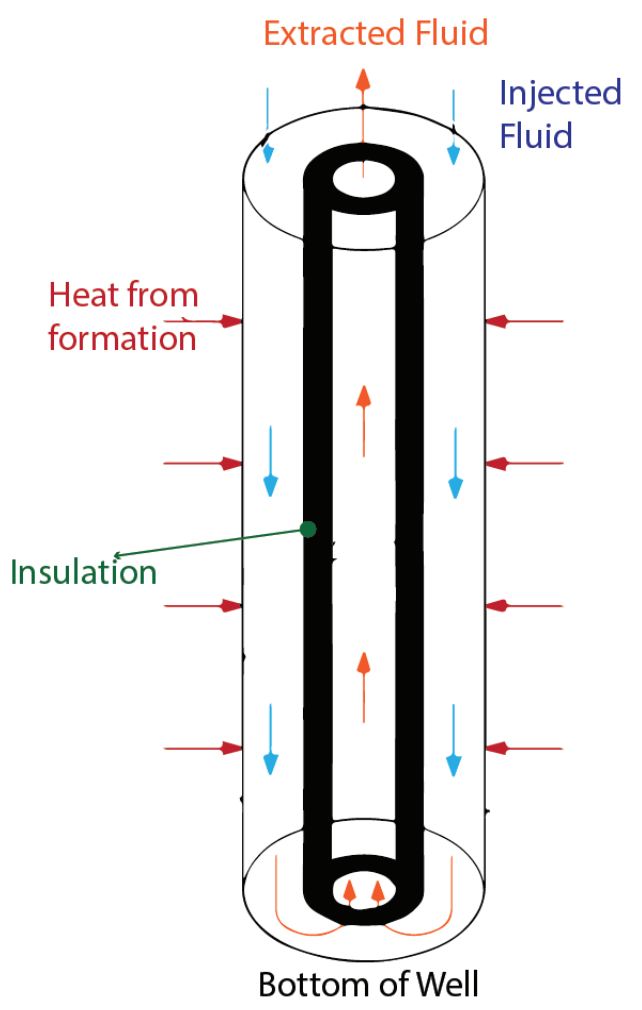

Gambar 3. Skema WBHX ((Bu, Ma, \& Li, 2012).

Berbagai studi telah menunjukkan bahwa WBHX untuk aplikasi pada lapangan minyak tua layak secara konsep, namun sampai saat ini belum ada proyek percobaan sama sekali. Terdapat beberapa kendala teknis yang telah teridentifikasi untuk konsep WBHX ini (Nalla, Shook, Mines, \& Bloomfield, 2005):

- Ada kompromi dari laju alir tinggi dengan ekstraksi energy. Semakin tinggi laju alir (untuk meningkatkan laju transfer massa), semakin rendah transfer panas yang terjadi dari formasi ke working fluid.

- Insulasi yang bagus antara bagian dalam pipa 
dan luar pipa sangat krusial untuk menjaga suhu dari working fluid yang naik ke permukaan. Kesulitan untuk memproduksi pipa dengan dinding ganda menjadi halangan untuk aplikasi di dunia nyata $(\mathrm{Bu}, \mathrm{Ma}, \& \mathrm{Li}$, 2012).

\section{Konversi Dari Reservoir Minyak Ke Reservoir Egs}

EGS (Enhanced Geothermal System) merupakan penggunaan energy panas bumi yang melibatkan ekstraksi panas dari sumber panas bumi dengan permeabilitas yang rendah atau tidak ada sama sekali. Berbeda dengan reservoir panas bumi konvensional yang umum digunakan, reservoir EGS mengumpulkan energy panas bumi dengan memompakan fluida dari permukaan ke formasi, menginduksi fraktur yang kemudian dapat dialiri oleh fluida. Metode ini dapat digunakan untuk lapangan minyak yang telah habis ataupun yang masih dapat berproduksi dengan menggunakan beberapa infrastruktur yang umumnya tersedia pada berbagai lapangan minyak (Singhal, 2018).

\section{Pembangkit Siklus Orc}

Dalam setting sedimentasi, suhu umumnya sangat tergantung dari gradien panas bumi, dimana semakin dalam sumur, maka suhu akan semakin tinggi. Karena itu, sangat mungkin bahwa sumur dengan kedalaman yang rendah tidak akan memiliki cukup suhu tinggi untuk dapat dipergunakan secara ekonomis untuk pembangkit listrik, bahkan dengan pembangkit binary ORC. Namun energy panas yang terbatas tersebut masih dapat dimanfaatkan untuk penggunaan langsung, sama halnya dengan penggunaan langsung panas bumi pada sumber panas bumi dengan temperature sedang dan rendah di Indonesia dan di seluruh dunia.

Pada penggunaan langsung, air panas atau hangat yang terproduksi tidak digunakan untuk

Tabel 1. Penggunaan langsung energy panas bumi (Adityatama, Purba, \& Kristianto, 2018)

\begin{tabular}{|c|c|c|c|}
\hline $\begin{array}{l}\text { Direct Use } \\
\text { Application }\end{array}$ & Utilization & Example & $\begin{array}{l}\text { Geothermal Fluid } \\
\text { Temperature }\end{array}$ \\
\hline \multirow{3}{*}{ Tourism } & $\begin{array}{l}\text { Recreational } \\
\text { swimming }\end{array}$ & $\begin{array}{c}\text { Darajat, } \\
\text { Batukuwung } \\
\text { (Indonesia) }\end{array}$ & $70-80{ }^{\circ} \mathrm{C}$ \\
\hline & Bathing/spa & $\begin{array}{l}\text { Waikita Thermal } \\
\text { Spring (NZ) }\end{array}$ & $98^{\circ} \mathrm{C}$ (discharged from spring) \\
\hline & $\begin{array}{l}\text { Integrated } \\
\text { tourism \& } \\
\text { cultural village }\end{array}$ & $\begin{array}{c}\text { Whakarewarewa } \\
\text { Thermal Village } \\
\text { (NZ), Blue Lagoon } \\
\text { (Iceland) }\end{array}$ & $220-240^{\circ} \mathrm{C}$ (reservoir temperature) \\
\hline \multirow{5}{*}{ Agriculture } & Timber drying & Tauhara Field (NZ) & $300^{\circ} \mathrm{C}$ (reservoir temperature) \\
\hline & $\begin{array}{l}\text { Palm sugar } \\
\text { plant }\end{array}$ & $\begin{array}{l}\text { Lahendong } \\
\text { (Indonesia) }\end{array}$ & $80-98{ }^{\circ} \mathrm{C}$ (shallow well temperature) \\
\hline & $\begin{array}{l}\text { Mushroom } \\
\text { cultivation }\end{array}$ & $\begin{array}{l}\text { Kamojang } \\
\text { (Indonesia) }\end{array}$ & $150{ }^{\circ} \mathrm{C}$ (well temperature) \\
\hline & $\begin{array}{l}\text { Copra \& cocoa } \\
\text { drying }\end{array}$ & $\begin{array}{l}\text { Way Ratai } \\
\text { (Indonesia) }\end{array}$ & $\begin{array}{c}92-95^{\circ} \mathrm{C} \text { (temperature discharged from } \\
\text { manifestation) }\end{array}$ \\
\hline & Prawn farm & $\begin{array}{l}\text { Huka Prawn Farm } \\
\text { (NZ) }\end{array}$ & $97{ }^{\circ} \mathrm{C}$ (from the reinjection brine) \\
\hline $\begin{array}{c}\text { Space } \\
\text { Heating }\end{array}$ & Hospital & $\begin{array}{c}\text { Rotorua Hospital, } \\
\text { Taupo Hospital } \\
\text { (NZ) }\end{array}$ & $\begin{array}{c}130-160{ }^{\circ} \mathrm{C} \text { (wellhead temperature of } \\
\text { the well) }\end{array}$ \\
\hline
\end{tabular}


pembangkit listrik, melainkan untuk pemanas. Meskipun Indonesia merupakan negara tropis dimana tidak dibutuhkan fasilitas pemanas, namun air hangat $\left(\mathrm{T}<100^{\circ} \mathrm{C}\right)$ yang diproduksi masih dapat dipergunakan untuk keperluan pengeringan produk agrikultur seperti coklat, kopra, atau penumbuhan jamur (Adityatama, Purba, \& Kristianto, 2018). Tabel 1 menyarikan berbagai penggunaan langsung panas bumi dari seluruh dunia.

Diagram Lindal (Gambar 4) merupakan cara yang efektif untuk menyarikan dan mengilustrasikan berbagai penggunaan dari fluida panas bumi berdasarkan temperaturnya (Patsa, Zarrouk, \& van Zyl, 2015). Lindal Diagram meliputi penggunaan langsung dari peternakan ikan, kolam air panas, pemanas ruangan dan rumah kaca, dll. Meskipun secara eknomis, penggunaan langsung kemungkinan tidak seatraktif untuk produksi listrik, namun aplikasi tersebut dapat digunakan untuk pengembangan komunitas local di sekitar lapangan minyak. Sebagai contoh, di Way Ratai, air panas dari sumur dangkal di area tersebut digunakan untuk pengeringan kopra dan ckokoa oleh komunitas warga local di sekitar area tersebut, memberikan nilai tambah bagi produk agrikultur mereka tanpa perlu untuk menghabiskan uang untuk bahan bakar minyak.

\section{PEMBAHASAN}

A. Potensi Penggunaan Di Indonesia

Dengan sejarah panjang dari produksi

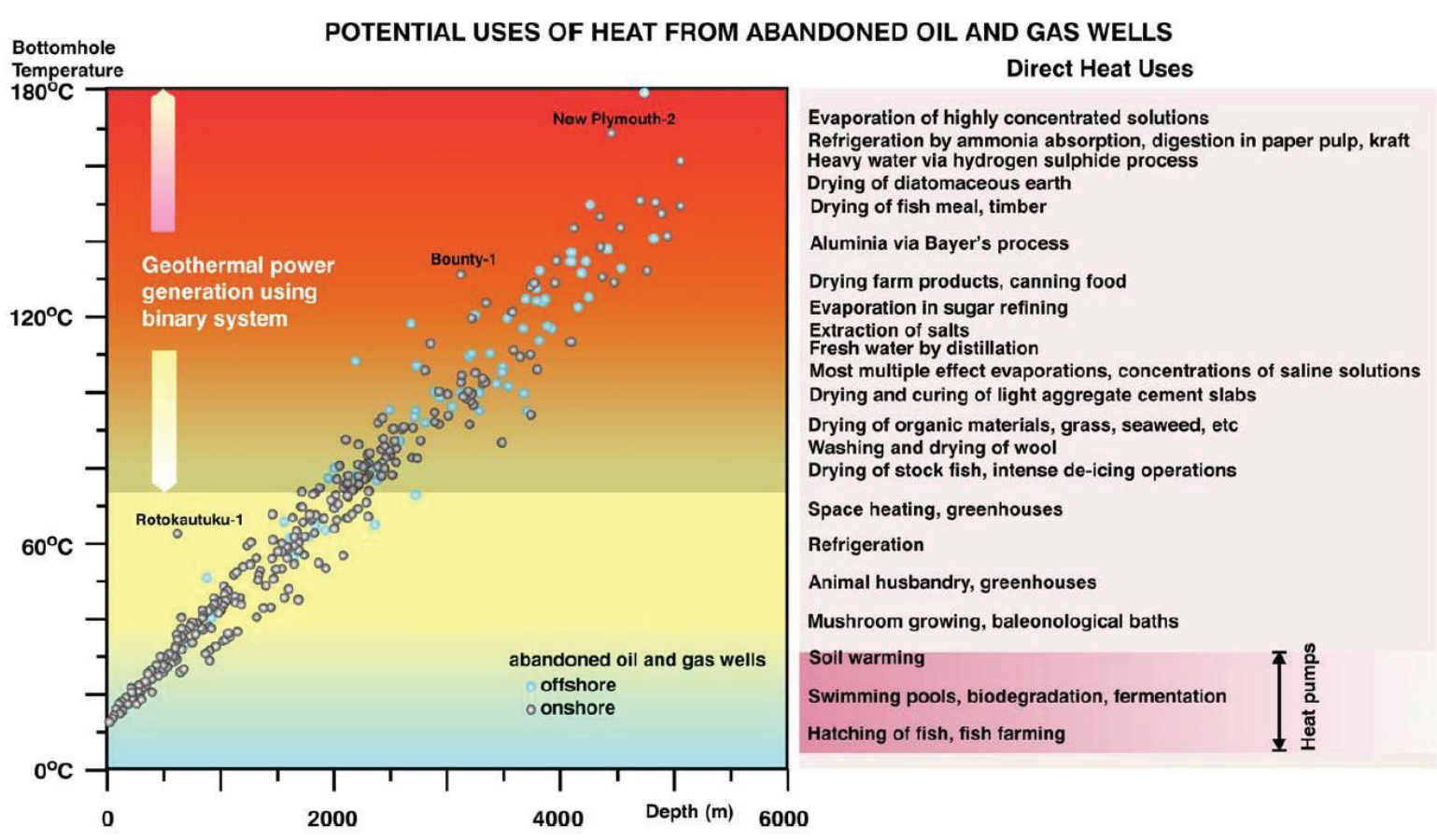


minyak dan gas, Indonesia memiliki banyak lapangan tua yang telah menurun produksinya atau bahkan tidak berproduksi sama sekali. Salah satu lapangan tua tersebut adalah lapangan Arun di Aceh. Karakteristik dari lapangan Arun dirangkum pada Tabel 2. Studi dari Syarifudin et al., (2016) memperkirakan apabila semua sumur di Arun yang telah tidak berproduksi digunakan untuk produksi air panas dengan laju alir 26.5 $\mathrm{kg} / \mathrm{s}$ dan suhu $170^{\circ} \mathrm{C}$, maka lapangan Arun dapat menghasilkan energy listrik sekitar $2900 \mathrm{~kW}$.

Tabel 2. Karakteristik lapangan Arun (Syarifudin, Octavius, \& Maurice, 2016).

\begin{tabular}{|c|c|}
\hline Profile & Value \\
\hline Producing formation & Limestone \\
\hline Mean depth (m) & 3,048 \\
\hline Productive area (acre) & 21,450 \\
\hline $\begin{array}{c}\text { Average net pay zone } \\
\text { (m) }\end{array}$ & 153.3 \\
\hline $\begin{array}{c}\text { Average pressure (psi) } \\
\text { Average temperature } \\
\left.\text { ( }{ }^{\circ} \mathbf{C}\right)\end{array}$ & 7100 \\
\hline $\begin{array}{c}\text { Non-producing well (in } \\
\text { 2013) }\end{array}$ & 178 \\
\hline
\end{tabular}

\section{B. Potensi Risiko dan Tantangan}

Terdapat beberapa risiko dan tantangan yang berhubungan dengan konsep konversi lapangan minyak dan gas tua menjadi fasilitas produksi listrik tenaga panas bumi:

- Keberadaan bahan - bahan beracun dan mudah terbakar. Reservoir minyak dan gas umumnya mengandung berbagai bahan beracun dan mudah terbakar seperti hidrokarbon, logam berat, hydrogen sulfida, dll. Rencana mitigasi yang matang harus dibuat dan diaplikasikan untuk mencegah atau memisahkan bahan bahan tersebut agar tidak bocor selama produksi.

- Risiko turunnya permukaan tanah. Karena produksi melibatkan ekstraksi fluida dalam jumlah besar dari bawah tanah, ada kemngukinan yang cukup tinggi untuk permukaan tanah mengalami penurunan. Manajemen reservoir yang baik dan monitoring harus dilakukan untuk mencegah kejadian tersebut yang berpotensi merusak fasilitas produksi.

- Teknologi yang belum matang. Beberapa konsep dan gagasan untuk menghasilkan energy panas bumi dari lapangan minyak dan gas tua masih dalam tahap riset dan pengembangan tanpa adanya aplikasi komersil. Bahkan ekstraksi fluida konvensional dengan pompa dan pembangkit dengan ORC masih terkendala dengan umur pakai downhole pump yang sangat terpengaruh oleh suhu tinggi dari fluida yang dialirkan.

\section{KESIMPULAN DAN DISKUSI}

Gagasan untuk menggunakan lapangan minyak dan gas tua untuk pembangkit panas bumi telah didiskusikan secara luas di seluruh penjuru dunia dengan percobaan yang sukses di Amerika Serikat dan China. Terdapat berbagai keuntungan yang dapat diperoleh apabila sumur minyak yang telah menurun produksinya atau bahkan sumur yang tidak berproduksi lagi dapat di konversi menjadi fasilitas pembangkit panas bumi. Dengan sejarah panjang produksi minyak dan gas, Indonesia memiliki banyak lapangan minyak dan gas yang dapat digunakan untuk fasilitas penggunaan panas bumi. Meskipun begitu, dengan kondisi saat ini dan status teknologi yang masih belum matang dan teruji secara komersil, masih ada beberapa tantangan teknis yang harus dipertimbangkan atau dipelajari lebih lanjut.

Studi ini merupakan langkah awal untuk menyarikan pengalaman penggunaan lapangan minyak dan gas tua di seluruh dunia untuk fasilitas produksi panas bumi dan potensi untuk aplikasi serupa di Indonesia. Studi - studi berikut harus dilakukan apabila konsep serupa ingin diterapkan di Indonesia:

- Pemetaan mendetail dari semua lapangan minyak dan gas tua di Indonesia. Hal ini harus dilakukan untuk menaksir potensi dari fluida yang ingin diekstrak, terutama dari segi suhu yang dimiliki dan dapat dipergunakan untuk aplikasi apa. Pemetaan ini meliputi tinjauan dari semua pustaka mengenai sumur sumur yang ada seperti akuifer, permeabilitas, tekanan dalam lubang, suhu, dll (Reyes, 2007). 
- Studi lebih lanjut mengenai efisiensi dari pembangkit binary. Hal ini krusial karena pada lapangan minyak dan gas tua umumnya tidak dapat mengalir keluar secara natural dan membutuhkan pompa untuk mengekstraksi fluida. Akan ada parasitic load yang sangat besar dari pompa yang akan sangat mengurangi net produksi listrik.

- Studi dan tinjauan mengenai status dan kondisi dari fasilitas lapangan minyak dan gas yang ada, seperti keadaan dari sumur yang telah ada (kondisi casing/tubing, liner, semen, korosi, dll.)

- Terakhir, studi menyeluruh dan mendetail mengenai kelayakan ekonomis harus dilakukan untuk konversi yang sukses secara komersil.

\section{DAFTAR PUSTAKA}

Adityatama, D., Purba, D., \& Kristianto, B. (2018). Integrated Geothermal Direct Use Facility as an Alternative Approach in Community Engagement at Early Exploration Phase in Indonesia. 7th ITB International Geothermal Workshop. Bandung.

Bu, X., Ma, W., \& Li, H. (2012). Geothermal energy production utilizing abandoned oil and gas wells. Renewable Energy, 41.

Davis, A., \& Michaelides, E. (2009). Geothermal power production from abandoned oil wells. Energy, 34.

Hettiarachchi, H., Golubovic, M., Worek, W., \& Ikegami, Y. (2006). Optimum design criteria for an Organic Rankine cycle using low-temperature geothermal heat sources. Energy, 32.

Johnson, L., \& Walker, E. (2010). Ormat: lowtemperature geothermal power generation. U.S. Department of Energy.

Kweik, R. (2015). Renewable Energy from Depleted Oil Fields Using Geothermal Energy. Dallas: Geothermal Lab Southern Methodist University.

Li, T., Zhu, J., \& Zhang, W. (2012). Cascade utilization of low temperature geothermal water in oilfield combined power generation, gathering heat tracing and oil recovery. Applied Thermal Engineering, 40, 27-35.
Ma, W., Li, H., \& Li, H. (2012). Geothermal energy production utilising abandoned oil and gas wells. Renewable Energy, 41.

Nalla, G., Shook, G., Mines, G., \& Bloomfield, K. (2005). Parametric sensitivity study of operating and design variables in wellbore heat exchangers. Geothermics, 34.

National Renewable Energy Laboratory. (2010). Geothermal Energy Production with Coproduced and Geopressured Resources. U.S. Department of Energy.

Patsa, E., Zarrouk, S., \& van Zyl, D. (2015). The Lindal Diagram for Mining Engineering. GRC Transactions, 39.

PWC. (2017). Oil and Gas in Indonesia: Investment and Taxation Guide.PricewaterhouseCoopers $(\mathrm{PwC})$ Indonesia.

Reyes, A. (2007). Abandoned oil and gas wells: a reconnaisance study of an unconventional geothermal resource. GNS Science.

Riney, T. (1991). Pleasant Bayou geopressuredgeothermal reservoir analysis. Energy Resources Technology, 114, 315-322.

Sanyal, S., \& Bulter, S. (2010). Geothermal Power Capacity for Petroleum Wells - Some Case Histories of Assessment. Proceedings World Geothermal Congress. Bali.

Shah, M., \& Agarwal, P. (2017). Predicting Direct and Indirect Uses of Geothermal Energy in Major Oilfields of China. Proceedings of 79th ISERD International Conference. Hong Kong.

Singhal, N. (2018). Geothermal energy production utilizing abandoned oil and gas wells: Indian scenario.

Soldo, E., \& Alimonti, C. (2015). From an Oilfield to a Geothermal One: Use of a Selection Matrix to Choose Between Two Extraction Technology. Proceedings World Geothermal Congress 2015. Melbourne.

Syarifudin, M., Octavius, F., \& Maurice, K. (2016). Feasibility of Geothermal Energy Extraction from Non-Activated Petroleum Wells in Arun Field. IOP Conference Series: Earth and Environmental Science, 42(1).

Umam, M. F., Muhammad, F., Adityatama, D. W., \& Purba, D. P. (2018). Tantangan Pengembangan Energi Panas Bumi Dalam 
Perannya terhadap Ketahanan Energi di Indonesia. Swara Patra, 8(3), 48-65. Retrieved from http://ejurnal.ppsdmmigas.esdm.go.id/ sp/index.php/swarapatra/article/view/6

Wang, S., Yan, J., Li, F., Hu, J., \& Li, K. (2016, September 30). Exploitation and Utilization of Oilfield Geothermal Resources in China. Energies. 